International Journal of Social Science And Human Research

ISSN(print): 2644-0679, ISSN(online): 2644-0695

Volume 04 Issue 12 December 2021

DOI: $10.47191 / \mathrm{ijsshr} / \mathrm{v} 4-\mathrm{i} 12-65$, Impact factor-5.586

Page No: 3930-3935

\title{
The Role of Prosodic Factors in Determining The Meaning of The Text
}

Khatira Avaz Gojayeva

Azerbaijan University of Languages, Phonetics department

ABSTRACT: Intonation is a very complex language unit. It has many functions, and these functions are performed by different phonetic events:

1. A phonetic event that performs the attitude function.

This function reflects attitude, emotion, and different phonetic events. For example, depending on the context of the speech and the current situation of the speaker, you can use falling intonation, rising intonation, falling-rising intonation, rising-falling tones.

2. A phonetic event that performs an accentual function.

This term is used in connection with an accent. Some phonetics also use stress instead of accent. In this function, the emphasis falls on the last lexical word, and the phonetic event of accentuation and clarification of intonation is performed.

3. A phonetic event that performs a grammatical function.

In this function, tone boundaries are defined by intonation. With the help of this phonetic phenomenon, the listener can better recognize the grammar and syntactic structure of what is being said.

4. A phonetic event that performs a discourse function.

The main task of this phonetic event is to convey to the listener what "new" information is. An eye-catching tonic accent is placed on the appropriate syllable of a particular sound.

KEY WORDS: intonation, text, prosodic, tone, movement, new, transmitted, information

\section{INTRODUCTION}

Prosodic means such as intonation, pause, and accent play an important role in the organization of text. Intonation is considered to be the main feature of the formal substantial organization of text. At the level of text, the intonation contours interact with each other to create its prosodic pattern. The elements that are used to make up the text, their beginning and end are more pronounced with intonation signs. Thus, the transmission of information has a key function in every oral text. This issue, i.e. the study of the transmission of information within the text, was still put forward by scientists from the Prague School of Linguistics. Then, in 1967, the issue of data transmission within the text was touched upon in the articles of M.A.K. Halliday. He (M.A.K. Halliday) was interested in studying the transmission of information within the text and the structure of information in general, the study of ways of its transmission. 2 categories of text information are defined: a) transmitted information; b) new information. To understand the meaning of the transmitted and new information, first consider the following sentence examples:

\begin{tabular}{|l|l|}
\hline SENTENCE & Transmitted and New information \\
\hline 1. It is the BOY who is petting the cat & Transmitted: $\mathrm{X}$ pets the cat \\
2. It is the CAT which the boy is petting. & New: $\mathrm{X}=$ THE BOY \\
3. The one who is petting the cat is the & Transmitted: The boy pets $\mathrm{X}$ \\
BOY. & New: $\mathrm{X}=$ the cat \\
4. What the boy is petting is the CAT. & Transmitted: $\mathrm{X}$ pets the cat \\
& New: $\mathrm{X}=$ the boy \\
5. The BOY is petting the cat. & Transmitted: The boy pets $\mathrm{X}$ \\
& New: $\mathrm{X}=$ pişik \\
& New: $\mathrm{X}$ pets the cat \\
& New: $\mathrm{X}=$ the boy \\
\hline
\end{tabular}

In these examples, we see that some words are capitalized. This is to emphasize the fact that these words are pronounced with a special intonation. It is clear from this that, as M.A.K.Halliday has shown, the role of intonation in the transmission of text 


\section{The Role of Prosodic Factors in Determining The Meaning of The Text}

information in English is irreplaceable. The reciever of the information understands the intention and purpose of the sender of information through the intonation that transmits or receives it. After some research, M.A.K.Halliday came to the conclusion that one of the main functions of intonation in English is to determine what kind of information the speaker conveys. In general, he (M.A.K.Halliday), who studied the transmission of information in the text, later tried to identify ways of organizing the information in spoken language. He associated this connection with phonological understanding. The intonation, as mentioned above, is observed to be central in this relationship. While studying the connection, the syntactic ways of information structure began to be explored. According to M.A.K.Halliday, the speaker combines his/her speech into information units. The speaker is free to give information on how to start and end it. For example,

/ John has gone into the garden with Mary // (Con Meri ilə bağa gedib).

The speaker can pass information by combining the sentence into several speaking units in this sentence:

a. /John has gone into the garden with Mary// (Con Meri ilə bağa gedib)

The information is given in a unit. Now let's look at how information is combined into one or more units:

b. /JOHN/- has gone into the garden with Mary// (CON - Meri ilə bağa gedib)

c. /JOHN/- has gone into the garden with/-MARY// (CON - bağa MERİ ilə gedib)

The 'internal organization technique' of an information syntagm is concerned with how new information is disseminated within that syntagm. M.A.K.Hallidey suggests that the speaker should place the given information before the new one. The 'unspecified' matching of the information structure is meant to be given-new information. Thus, within a text, a syntagm in capital letters or with an accent reflects only new information.

Tone movement, power, and pronunciation are also known to be key features in determining the information-important syntagm. For example:

/I haven's seen John since YESTERDAY// (DÜNӘNDӘN Conu görməmişəm)

In this example, being part of the text about / John /, then the movement of the tone begins with the middle tone of the speaker. It rises considerably over the component, and then gradually descends to the end, and as a result the intonation of relative exhaustion serves as the external organization of this syntagm. However, the rise and fall of the tone is also the movement of the intensity, the rise and fall, or the strengthening and weakening of the tone. This is almost a sign of a sentence stress.

Research suggests that each language developer develops a specific articulatory program and uses certain acoustic features to accomplish his or her communicative intentions. It turns out that the temporal and melodic components are relevant for intonation. It is undeniable that the division of text into syntagms in terms of structure and intonation plays an important role in its definition.

\section{DISCUSSION}

G. Brown and G. Yul write that in oral text the structural units are in the form of speech programs, and they can be called intonation units. The intonation curve is a signal to start a new paragraph. 'Speech paragraph' or 'paraton' is known by border marks, as in the spelling paragraph. Paraton shows the beginning, then makes a topical change in the conversation. In the beginning, the speaker states what is meant. This happens with a rising tone. The end of paraton shows that the text is over as a process. This can be expressed in a falling one, a weakening of the amplitude and a prolongation of the pause. It should be noted that F. Veysalli does not agree with the fact that the subjective side of the intonation mentioned by G. Brown and G. Yul should be considered to be more prominent. For example, their approach takes into account the age, gender, dialectical affiliation, etc. of the participants. When the elements are discussed, the intellectual side of the intonation curves that appear in them remains undiscovered. On the other hand, according to F. Veysalli, paraton cannot be taken as a unit of text. Because a tone can be a means of membership as a component of intonation, but it can never be a unit of membership. The syntagm theory developed by the L.V. Sherba school helps in such membership. Thus, F. Veysalli writes that in the internal membership of any text it is possible to take syntagm as a unit that has a phonetic whole effect, is a grammatically formed structure, and has a specific semantic meaning.

As we have mentioned, in the analysis of a living language, as well as in the analysis of text, along with semantic meaning, intonation, emphasis, etc. may also be important. At the same time, there is no denying the importance of experimental phonetic research. W. Chafe proposes to consider the unit of intonation in the structure of text, ie as a text quantum corresponding to one focus of consciousness. Each intonation unit usually contains an element of new information and indicates the interaction of the old / new information mix with the prosodic (accented / unaccented) and lexical (pronoun / noun) realization of referents in the text. In this case, it is important to determine the status of the information. M.A.K. Halliday writes about it: "The type of information is the choice made by the speaker, the choice of information does not depend on the context of the text or the situation; it is the speaker's choice to give the speaker new information and to remind him/her of the information already given in the text". M.A.K.Hallidey claims that the intonation contour of the tone group is united around the tone syllable: "There is always the highest peak tone among the tone groups. ... The tone syllable emphasizes the syllable that plays a key / leading role between tone groups". From this it is clear that there is simply a strong intonation movement within the tone group. It is noteworthy to stress that it is difficult to identify a single peak united around groups of tones. G.Brown, K.L.Kur and J.Kenvörs came to this conclusion with a series of experiments [Brown 1983, p, 158]. They claim that the boundaries of each unit needs to be defined. In contrast, M.A.K. Hallidey does not 


\section{The Role of Prosodic Factors in Determining The Meaning of The Text}

disclose the criteria for clarifying the boundaries of the unit to determine the tone of the peak. He argues that the indication of boundaries can be determined by the rhythmic / melodic structure of speech: a group of tones or groups as a phonological unit plays a key role in understanding the structure of information. The following example may illustrate our point of view:

// not only THAT but you // didin't know / where to start / LOOKing for the / other and a // GAIN as I say ... . (Nainki O, amma, sən də / bilmirdin haradan başlayasan/AXTARASAN/digərini/ ӘLDӘ EDӘSӘN/necə ki, mən demişdim. .. )

As can be seen, the unit of information given in this example reaches its peak in the middle of the word. The boundaries of these tone groups are clearly visible. They can really define the boundaries of information units in conversation.

A group of scholars working on text intonation emphasize the role of pause in a text as well.

The duration of the break, the choice of the time of the break can vary according to the intention of a speaker. Every speaker may not have his/her own break:

a. /but (o.8)//

b. /as (o.3) is well known (1.1)//

c. /it (o.2) very frequently happens that you you'll get a (o.3) co-occurrence of (o.2) an item with (1.o)//

d. /a recognised grammatical class (1.o)//

e. /erm (o.4) say a class of possessives or a class of (o.7)//

f. /erm negatives of one sort or another (o.6)//

g. /so that it is (o.4) erm (1.1)//

h. /we cannot restrict lexical patterning (o.6)//

i. /entirely to items as items (1.1)//

j. /erm (o.6)//

k. /whatever that may mean in itself may mean (1.2)// (The translation in Azerbaijan:

( - amma (o/8)

- məlim olduğu kimi (1.1), belə ki, (o.3)

- bəzi qrammatik mövzuların başlıqlarının bərabər istifadə hallarına rast gəlmək mümükündür (1.o)

- ee (o.4) yiyəlik halları, yaxud da bu və ya digər inkar halları (o.6)

- $\quad$ bu da onu ifadə edir ki, (o.4) ee (1.1)

- $\quad$ ee (o.6)

- bu nəyi ifadə edirsə (1.2))

(The figures in the example show the duration of the pause in a minute). As it is seen, the speaker pauses several times until he or she gives the intended information.

According to experts, there are the following types of breaks:

1. Extensive breaks: This type of break can cover a period of 3.2 to 16 seconds. This is a break for the speaker to understand the information or to write down what is being said. In the text, this type of break is indicated by a $/++/$ sign.

2. Long pauses: This type of pause lasts between 1.0 and 1.9 seconds. This interval is indicated by a $/+/$ sign.

3. Short breaks. These intervals are between 0.1-0.6 seconds. This type of break is indicated by a /-/ sign.

G. Brown and G. Yul claim that wide and long gaps play a role in defining information boundaries [Brown 1983, p. 93]. However, short breaks are also considered to be single intervals:

/And as he's holding onto the handlebars he takes off with them (1.1) Um - (o.7) then (o.4) uh - (2.1) a girl - on a bicycle (1.15) comes riding towards him . . in the opposite direction. / (O, velosipedin sükanını əlində saxlayır, velosipeddən düşür (1.1) Im - (o.7) sonra - (o.4) ah - (2.1) q1z - velosipeddə (1.15) ona tərəf gəlir ... əks istiqamətdən).

W. Chafe notes that the role of the pause in defining the boundaries of text information can be compared to the use of punctuation marks as terminal markers in a written text. It should be noted that W.Chafe considers the length of the break to be the time when the speaker plans to move on to the next speech: “.... the new borders of the paragraph refer to the breaks in the text. In the example above, the speaker pauses several times, and when he/she begins to speak again, he/she continues with another new piece of information" [Chafe 1974, p.33].

In this example, /....Um - and uh / - are called 'break fillers'. The hesitant pause time at the end of the first sentence and the time at the beginning of the other sentence are 6.25 seconds. Here the result of a clear and logical mental process is obvious. As can be seen, the long and wide intervals of the text researcher are used to define the boundaries of phonological units related to information units.

\section{ANALYSES}

It is true that the role of the pause in defining the boundaries of the text is controversial. What is controversial is the role in defining the boundaries of text. Some linguists claim that a pause plays a key role in defining the boundaries of text. Reformatiski writes about it: "The sentences that make up the text are processed with a certain pause. The pause regulates the tempo and rhythm of the sentence. Regulated sentences form a text such as /John had dulled himself to Emily, but he would have needed to blind himself to 


\section{The Role of Prosodic Factors in Determining The Meaning of The Text}

miss the change that came over her now// (Con Emili üçün özünü kütlüyə vurardı, amma o, indi ona üstün qəlmək üçün dəyişmək imkanını da əldən verməzdi)

In this sentence, the intonation components play a key role in conveying the information.

Thus, we conclude from the analysis that prosodic factors (intonation, accent, tempo, rhythm, pause, etc.) play a leading role in the formation of text, the definition of its boundaries, etc. We would like to emphasize that the acceptance of the information conveyed by the speaker as new information and defined as a phonological peak, or whether the information is given and not marked with a phonological peak does not depend on the structure of the text [Coulthard 1977, p.12]. It depends on what the speaker wants to say and how his/her listener perceives the information. Let us see the example:

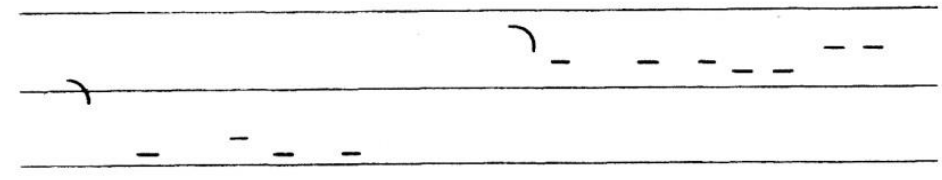

/even the dancing + dancing's no really a pastime//

(hətta rəqs + rəqs həqiqətdə əyləncə deyil)

In this example, the speaker not only reminds the referent, but also uses a low tone when talking about him/her, considering him as the given information. The speaker talks about the dance, concludes his/her first comment in a low tone, then introduces a new comment about it and uses the phonological peak. Thus, the division of information into new or given categories, as justified by M.A.K. Halliday, is not confirmed [Craig 2001, p.125].

Text plays an important role in disseminating information, drawing up a daily action plan, and analyzing the past and looking to the future. This is equally important for all types of texts. The grouping of theoretical concepts, the formation of a new direction, controversy, a critical approach to heritage and a hopeful view of the future are the basis of scientific text. In all these works, choice, form and intonation, as well as space and conditions play important roles. How to start a conversation and how to end it is the first factor that captures the audience. A. Mammadov and M. Mammadov pay special attention to keeping the audience in sight, as well as to making the interaction interesting [Mammadov A., and Mammadov M., 2010, p.23]. Postulates, programs, advertisements and conferences are relevant forms of scientific text. Conferences and advertisements should be aimed at opening and promoting the concept of a particular scientific school. At the conference, the report reflecting the main provisions of the concept should be made by a leading expert and highlight the school's scientific contribution with its generalizations.

R. Dale does not say in vain that text is such an object of propaganda that it reflects the world created by the subject. The world is not given to man directly, it is created and interpreted by man himself, and we create the world with our own psyche [Dale 1990, p.13].

Language is a means of connecting people with people and the environment as a whole. Any interpretation must bring the existing system to life in any text. In fact, it is both explicit and implicit. First, industry leaders analyze and evaluate the situation. In the second, everything must be renamed and defined. The definition of a leader continues as it is. The creative approach plays an important role here [Scott 1990, p. 11].

In traditional linguistics, the connection of a word and a sentence to a word or sentence before and after it, as well as the study of their relationship with other objects and real reality, played a crucial role [Chafe 1974, p.111]. Metalinguistics of these aspects necessitates the development of a number of specific terms.

As we have noted, a pragmatic approach to language learning is more important in terms of usage. In other words, the formal approach is not so important in this approach. In order to clarify the information in the area where the text is encountered, deictic forms, for example, / here, there, I, you, this, that, et./ are used. In addition to dexterity, there is reference, proposition, implication, infection, and other terms that can be applied too.

According to J.Lyons, the connection between a word and an object can be called a reference. This traditional view is a linguistic expression of the relationship between the language and the world. Later, J. Lyons puts forward the following idea: the speaker refers (in various appropriate expressions); it detects the required expression through reference. In this regard, Stroson argues that citation is not something that is expressed; it is a means by which the speaker uses appropriate expression. In connection with this opinion, J.Searle's view is like this: expressions express nothing but promises or orders. According to F. Veysalli, the connection between the sign and the material world - the referent connection must be taken into account in the analysis of text. Thus, in text analysis, a reference is understood in the sense of the speaker or the writer acting. Let's analyze the following example:

A: /My uncle's coming home from London on Sunday + he's due in +// (/Omim bazar günü Londondan gəlir//)

B: ?How long has he been away for or has he just been away? (?O nə qədər vaxtdır gedib, yoxsa o təzə gedib?)

A: /Oh no they lived in London eh he was married to my mother's sister + well she's been dead for a number of years now +// (/Ah, xeyr onlar Londonda yaşayırdılar, o mənim xalamla evli idi. O, artıq bir ildir ki, ölüb//)

In this dialogue, the speaker A uses the expressions /my uncle/ and / he / for one individual, / my mother's sister / and / she / for the other. . Apparently, the word / uncle / is the referent of / he /, and / my mother's sister / is the referent of the other / he /. 


\section{The Role of Prosodic Factors in Determining The Meaning of The Text}

All these connection issues help to determine the proposition in the text. R.Stalnaker also defined proposition in this regard. He writes: 'Proposition is an idea that the speaker acquires or can capture during the conversation of the participants within the general topic'. It should be noted that in both of the above quotations, the main source of proposition is the speaker.

There are usually several types of proposition opening:

1. The existence of an actual verb. For example /Sona was sorry to have seen Johny// (Sona Conini gördüyünə təəssüflənirdi// - Sona Conini görüb;

2. Proposition of implicative as well as conditional verbs. For example, /He was able to open the door, and he stopped to play the piano//

/O, qapını açmağa nail oldu// (yəni açdı) və /O, piano çalmağını dayandırdı// (O əvvəllər piano çalarmış);

3. Iterative verbs. For example,

/Johny again came//

/Coni yenə gəldi// (əvvəllər gələrmiş);

4. Verbs of judgment. For example, /Johny accused him/her to have stollen his car// /Coni onu maşınını oğurlamaqda günahlandırdi// (Coni hesab edir ki, o oğrudur)

5. Adverbial clauses of time. For example, /When he died, the problem hadn't been solved yet// /O öləndə problem hələ həll olunmamışdır (onun ölməsi)//

For the term implicature, H. P.Grice used the term inclusive to take into account what the speaker meant, suggested, or intended. That is, according to H.P. Grice, traditional implicatures are defined by the traditional meanings of the words used. Let's look at the following example: /He is an Englishman, he is, therefore, brave// (/O ingilisdir, o, ona görə də cəsurdur//)

We can analyze this sentence as following: one supposed trait (being brave) does not follow another trait (being English), but the traditional form of expression is a sign that there is such a connection. In general, the use of implicature makes it easier to understand. And it is a selective meaning, that is, infection. Traditional implicature conversation + consists of a group of principles that the speaker must follow. Although this is not fully expressed, it is understood as a result of content. This can also be taken as a type of presupposition. H.P. Grice calls this the principle of negotiation.

The other example:

A: /I am out of petrol// (/Benzin qurtarib//)

B: /There is a garage round the corner// (/Küncdə yanacaq doldurma var//)

In this example, the addressee joins the conversation in accordance with the principle of connection, expresses his/her attitude to what is said. The principle of coherence manifests itself here as well. The listener has to make his/her own choice. For example,

/I saw Tom going to school// (/Mən Tomu məktəbə gedən gördüm//)

/Tom couldn't manage to finish checking the control works yesterday// (/Tom dünən yazı işlərini yoxlayıb qurtara bilmədi//)

Consider another example:

a. /If it is sunny, it is warm// (/Ogər hava günəşlidirsə, deməli istidir//)

b. /It is sunny// (/Bu gün hava günə̧̧lidir//)

c. /So, it is warm// (/Deməli, istidir//)

In these examples, sunny weather means to be warm.

We can define proposition at the sentence level. The fact that my uncle came from London first, when he came second, why he went to London and married our cousin's daughter, and finally the girl's death can be considered a proposition of the sentences in that text. All of these sentences are real, grammatically correct constructions with specific meanings.

Proposition is derived from the English word presupposition, which means / to assume/. A proposition is a basic idea that is considered to be the basis for the speaker's general conversation, but can be easily identified even if it is not directly present in the text. Based on the above examples, we can explain that in order for A to understand the speaker correctly and for the presumption to be correct, speaker B enters the sentence into the dialogue, but does not express his/her opinion clearly. So, the presupposition in this dialogue is that by using that sentence, he/she constructs the information he/she will give to A B so that his/her interlocutor understands that the speaker is referring to his uncle. A then continues the conversation and announces that his uncle is getting married to a relative and that the girl died a few years ago. The proposition in text analysis is a pragmatic proposition.

As T. Givon claims, the listener can capture the thought of the speaker without any confusion. He compares intratextual coherence with thought coherence and focuses more on the cognitive interpretation of coherence. According to T. Givon, the internal structure of text is conditioned by several factors: the unity of subject and participant, the unity of time, the unity of space, and the unity of movement. He focuses on the reference relationship between the types of thematic connections within the text. In this regard, he distinguishes the return to the previous experience, so to speak, retrospective and future-oriented - prospective view as a type of reference relationship. T. Givon characterizes these species in terms of their formal indicators. For example, he 


\section{The Role of Prosodic Factors in Determining The Meaning of The Text}

notes that retrospective correlation refers to a relation to a definite referent, and prospective correlation refers to a relation to a reference to uncertainty.

\section{CONCLUSION}

Determining the nature of a text is known to be one of the most important factors. The text and its connection, no interrelation of meaning has a point of development between the components in a clear, isolated form from others. Other types of meanings are always added to a semantic relationship to one degree or another. At the same time, they note that in multi-component texts, it is not necessary for any semantic relationship to manifest itself from the beginning to the end of the text as different types of semantic connections can take place within the text.

It should be noted that the role of prosodic factors in determining the discourse, revealing its essence is undeniable. The role of prosodic actualization in the regulation of the text has already been proved. Accent, intonation, pause have special roles in the regulation of sentences that make up the text. They organize the sentence and create a text of ordered sentences.

In English, the intonation of new information is distinguished by the logical emphasis of the word that expresses it. Therefore, logical emphasis is one of the main indicators in determining the text. Pause during pronunciation or reading also plays an important role in determining the text. The pause is closely related to other prosodic means, as it essentially changes the communicative aspect of the sentence.

\section{REFERENCES}

1) Brown G, Yule G. (1983) Discourse Analysis. Cambridge: Cambridge University Press.

2) Brazil D., M.Coulthard, C.Johns. (1980) Discourse intonation and language teaching. London: Longman Higher Education.

3) Brown G., Yule G. (1983) Discourse Analysis. Cambridge: Cambridge University Press.

4) Chafe W. (1994) Discourse, consciousness, and time. The flow and displacement of conscious experience in speaking and writing. Chicago: University of Chicago Press.

5) Chomsky N. (1969) Aspects of the Theory of Syntax. England, MIT Press.

6) Coulthard R.M. (1977) An introduction to discourse analysis. London: Longman.

7) Craig R.T. (2001) Communication. Encyclopedia of Rhetoric. / ed. T.O.Sloane. Oxford: Oxford University Press, pp. 125137.

8) Crystal D. (1995) The Cambridge Encyclopaedia of the English Language. Cambridge: Cambridge University Press.

9) Chafe W.L. (1974) Language and consciousness. Chicago: Universety of Chicago Press.

10) Chafe W.L. (1979) The flow of thought and the flow of language. in (ed) T.Givon. Chicago: Universety of Chicago Press.

11) Dale. R. (1990) Generating Recipes: An Overview of Opicure. R.Dale, C.Mellish and M.Zock. London: Current Research in Natural Language Generation. Academic Press.

12) Kukharaenko V.A. (1986) A Book of Practice in Stylistics. Moscow: New Press.

13) Scott, D., C.S.de Souza. (1990) Getting the Message Across in RST-based Text Generation. London: Current Research in Natural Language Generation Academic Press.

14) Mammadov A., Mammadov M. (2010) Cognitive perspectives of discourse analysis.Baku: Chashioglu. 